\title{
In vitro fertilisation: the major issues
}

\author{
Teresa Iglesias Linacre Centre, London
}

\section{Editor's note}

The author, a Roman Catholic philosopher specialising in medical ethics, continues the debate on in vitro fertilisation started in the last issue of the journal by Professor Singer, Deane Wells MP and Professor Mitchell. She argues that the widely accepted principles embraced within' respect for persons' undermine both utilitarianism and attempts to exclude any group of human beings from their application.

The acquisition of desires or of sentience or of selfconsciousness cannot determine the acquisition of rights or the moral status of personhood, she argues; . . . 'to be a human being is to be a person. There are no stages in our existence at which this identity does not hold. . . It is in virtue of what human beings are right from the beginning of their existence that they must be accorded absolute respect and their lives treated as inviolable.'

\section{The issues}

One of the fundamental critical comments that Professor Mitchell makes in his contribution to the recent JME symposium (1) on in vitro fertilisation (IVF) is that consideration of the well-being of the child to be brought into existence by artificial methods of reproduction does not feature prominently in Professor Singer's and $\mathrm{Mr}$ Wells's discussion. In his reply Professor Singer seeks to rectify this impression and clarifies their position which, he says, 'rests solidly on utilitarian foundations' and 'naturally' - he adds - 'in making our utilitarian calculations, the interests of the potential child must also be taken into account'. It emerges that consideration of the wellbeing of the child is far from being an overriding factor in the utilitarian calculation. Even if the children generated in an artificial way will be subject to disadvantages directly attributable to that mode of generation, as long as these disadvantages are not so serious 'as to make their lives so miserable as not to be worth living' we may proceed with this mode of generation. Singer goes on to claim that it would require distinctively high 'suicide rates' to show that

\section{Key words}

In vitro fertilisation; human embryo; human rights; medical ethics; personhood. 'these children do not find their lives worth living'.

Singer's only way of envisaging the good of the child as it is relevant to determining the acceptability of IVF (in whatever context) and surrogate motherhood, is by way of answer to the question: would children conceived and reared in these ways get sufficient satisfaction out of life to prevent them committing suicide? It is clear that he lacks any objective conception of the values and goods which make for authentic human development and therefore any conception of normative conditions conducive to fostering those values and goods. The child enters the utilitarian calculation simply as one among a number of potential points at which desires are satisfied. If, like Singer, you imagine yourself able to predict a surplus of satisfied over unsatisfied desires in the life of that child, then there is nothing to count against satisfying another person's desire to have that child.

Apart from (i) the well-being of the child-to-be, the other issues discussed in the symposium which I take to be major are (ii) the family as a natural structure of human life (as natural as language), its relation to marriage and to the different forms of artificial parenthood, and (iii) the nature of the human embryo.

Other questions, such as the allocation of resources (and the neglected question of infertility) I take to be directly related to the general issue of the ultimate aims of medicine. In my view the essential aim of medicine is the restoration to health (or some approximation of health) of those diseased or impaired, and not the satisfaction of other needs (least of all 'needs' for which our only evidence is strong desire). On Professor Singer's conception of need there can surely be no rational way of settling resource allocation problems.

Professor Mitchell gives full consideration to the essential social dimension of the issues, particularly to the family founded on the marriage covenant as the natural context of generation. He indicates how if one followed the views and recommendations of Singer and Wells our society would be deleteriously affected. I share his point of view and believe that to be married is a fundamental condition for assuming the responsibilities of procreation, and that this is not - in moral terms - a mere matter of attitude, as we are told.

That Professor Singer's and Mr Wells's views 'are 
likely to obtain a.great deal of support from medical scientists and medical practitioners' is a fact too obvious to require emphasis; it shows the extent to which the prevailing medico-scientific ideology and practice have become utilitarian.

Nevertheless, it is not the case, either in theory or in practice or as a matter of tradition, that utilitarianism in its variety of forms - is the only way or the best way to evaluate and solve our moral and social problems. Indeed, there are alternatives to the utilitarian mentality which are worth considering. My purpose here is to present one briefly. My contribution will centre around the issue I take to be basic and which deserves closer attention than was given to it in the symposium. It is an issue on which most of the other moral and social issues raised by IVF depend: the nature of the human embryo.

There are two inevitable routes that I must follow in order to tackle the problems; they can be called the moral and the ontological.

The former route issues in recognition of the values belonging to things, values which govern our behaviour and command our respect; such values as belong to things establish their moral status. The latter route issues in recognition of the nature of things what they are or what the facts show of their mode of being - their ontological status. These two routes are interrelated, for we need to know what things are as a necessary presupposition for knowing how we should treat them, and the kind of respect owing to them.

\section{The moral evaluation}

What kind of respect is due to the human embryo? We cannot answer this question without first giving an answer to another one: what kind of respect is due to the developed human being or human person? The most basic reply we must give to this latter question may be framed in a simple principle: no human being is property - or what is the same - no human being can be treated as property. That some human beings have been regarded and/or treated as property by other human beings is both an historical and a current fact.

Historically, slavery best illustrates the point. The social institution of slavery made one human being, as a matter of law and practice, the property of another human being. The slave had no claim over his or her life and liberty. He could be used, exploited or even killed and so his life was of purely instrumental value. A slave, both in his life and powers, was radically a means to the interests and benefit of his master.

Currently, some have argued that infants (and even young children) are the property of their parents. So parents have the right to dispose of them if it is deemed desirable or beneficial. It is claimed that children do not have equal moral status to the fully developed human being, so they can be used for the benefit of others, as in medical experiments; to this kind of end they can be generated and subsequently disposed of. If children are property then they can be treated as property.

The abolition of slavery for every human being $-\overline{\bar{\gamma}}$. including children - may be taken as one of the greatest steps in the moral development of the human family. It $\overrightarrow{\bar{s}}$ amounts to the recognition of the fundamental moral 7 equality of all human beings. Indeed, human beings are not properties, objects or instruments of use to $\bar{\omega}$ serve the benefits and interests of others. 'No human being is property' is a moral premise of our contemporary society which expresses an egalitarian vision of man, attained through long social struggle $\vec{\circ}$ and by the suffering lives, and deaths of many individual human beings.

Recognising the radical equality of status of all members of the human family leads us also to recognise $\Phi$ what might be meant by the principle of 'respect for $\overrightarrow{0}$ persons'. This respect is a fundamental requirement of $\overrightarrow{.}$ justice, in virtue of which no human being is to be used $\underset{N}{\omega}$ or exploited for any purpose whatsoever. It is a 은 recognition that individually every human being at least has the right not to be used merely as means to the $\bar{z}$ needs or interests of others and every innocent human being has at least the right not to be killed. 'Not to be $\stackrel{\Im}{\supset}$ used, not to be killed', is the ultimate moral ground $\vec{\oplus}$ where the roots of justice lie. So it is the point of $\stackrel{\infty}{\oplus}$ departure for our dealings with one another in all the 0 social contexts and social forms of life in which we find ourselves and which we continuously create.

The moral equality proper to all members of the human family not only pervades our international declarations and bills of rights: it is also enshrined in our laws which are designed to guarantee and protect the inviolable status of every individual human being. The equality of humans is central to the moral vision of the medical profession, in its attempt to serve life, as expressed in its codes of practice. The paramount value of each human being and the consequent moral necessity to respect it also constitutes a corner stone or first principle of traditional moral philosophies (the $\dot{\delta}$ Kantian one being an example) as well as a corner stone $\overline{2}$ of religious moral thinking and life as in, for example, 우 the Jewish-Christian tradition. Yet, for the utilitarian tradition respect for the individual human being is not o the paramount moral value; the paramount moral value is rather the realisation of some overall 'best os outcome', to achieve which values and persons may be $N$ sacrificed. Accordingly, if the circumstances seem to $\mathrm{C}_{\mathrm{N}}$ require it, the life or lives of individual human beings 0 may be regarded as instrumental, and expendable for that 'greater good'. Ultimately, in utilitarianism, all values can be traded off, human beings themselves can $\stackrel{\mathcal{D}}{\rightarrow}$ be. This is not so for the kind of non-utilitarian outlook 0 I want to present. In this outlook any 'calculations' or ${ }^{\circ}$

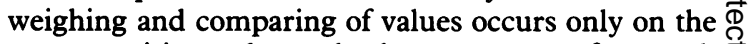
presupposition that absolute respect for each $\stackrel{\Phi}{\Phi}$ individual human being is under no circumstances to $\frac{a}{\sigma}$ be 'traded off' ie the direct harm or destruction of innocent human life is never regarded as justifiable. In 8 this perspective all human beings are to be treated as morally equal. 
Yet some non-utilitarians may ask: 'Are all human beings really equal?'. 'Are we not to distinguish between the newly conceived human being - or the "potential human being" or "potential person" - and the fully developed human being, in full exercise of his or her personal capacities?'.

Professor Singer and $\mathrm{Mr}$ Wells claim in their discussion that they 'regard the $1,2,4,8,16$ or 32 cell zygote as not in the same category as a developed human being'. This means zygotes do not deserve the same moral respect accorded to the developed human being, since they are not the same kind of beings. The zygote and the developed human being differ in nature, ie in their ontological status, hence they differ in their moral status as well. Is this really so? To this question, I now turn.

\section{The nature of the human embryo}

When philosophers and scientists study the nature of things they do so by paying attention to their material (or bodily) configuration, to their behaviour and to the powers and capacities they manifest. In other words, they find out what specific things are by how they appear and what they do. So if we wanted to know about the nature of the human zygote, ie what the human zygote really is, it would not help us to characterise it as 'genetic material' or 'biological material' (to use Singer's and Wells's phraseology, now very much used by the medical profession as well), or as something having merely 'biological life'. These expressions do not specify the particular nature of the thing they refer to. By 'genetic material' we could equally mean a segment of DNA, or some of the genes, or all the chromosomes, or whole germ cells like sperm and the unfertilised ovum, or the zygote. By 'biological material' we could mean all the above plus any somatic cell or group of cells, or organs or even the living being as a whole. The attempt to reduce the human embryo to living material of no specific kind is both scientifically and philosophically incorrect. Let us remember as well that there is no such thing as 'biological life', for life strictly speaking only occurs, is sustained and transmitted in and through individuals; and individuals are always of specific kinds. There is, doubtless, a pragmatic advantage in describing the newly conceived human being as 'biological' or 'genetic material'; by a mere device of language you can make it seem that there is nothing wrong in using, experimenting on, destroying, freezing and disposing of embryos - which are just 'material'.

So if we are to discern the nature of the zygote we cannot do it by reducing it to mere biological material; we need to know what particular kind of material being the zygote is by its characteristic elements, structure, organisation, inner dynamisms and capacities. We can learn much from the biological sciences in this respect. Professor Singer in one of his writings has conceded this: 'When opponents of abortion say that the embryo is a living human being from conception onwards, all they can possibly mean is that the embryo is a living member of the species homo sapiens. This is all that can be established as a scientific fact. But is this also the sense in which every 'human being' has a right to life?' (2). (It should be noted that the expression 'homo sapiens' is not 'neutrally scientific' and bereft of the significant moral implications that some resist in the word 'human'; it might also be noted that from a scientific viewpoint a zygote is indeed a new item in the human species, while any other cell is not).

The fact that the zygote or embryo is a living human being from conception onwards is a sufficient reason for many to recognise that it must be treated and protected not as property but as a member of the human family. It must be respected in accordance with its particular life stage and condition; it must not be killed, it must not be used, instrumentalised or exploited for any purpose whatsoever. For many, including Singer and Wells, to be a human being ie a member of the human species, does not carry with it any claim on others to respect one's life. What carries this claim is the fact that a human being is in a sufficiently developed state (ie is a person) to make this claim in and through his desire to be so respected. Perhaps the two contrasting positions could be clarified in the following terms. The continuity of our existence as human beings, ie as members of the human species from our earliest embryonic beginnings, could be described as a dynamic process of becoming what we potentially are. This process, though, can be interpreted in two different ways: (a) as the process of development into a person, or (b) as the process of development of a person. The basic difference between these two interpretations lies in what the term 'potentially' is really taken to involve and in what is ultimately valued in human beings. Let me consider these two positions in turn.

\section{(a) Development into a person.}

In this approach it is maintained that we become persons, and may cease to be persons, while our existence as human beings persists all the time. Two unavoidable questions arise: (i) in virtue of what are we to be considered as persons? and (ii) at what stage of our development as human beings do we become persons? (i) Philosophers in the tradition of Locke say that a person is an organism possessing 'the concept of self as a continuing subject of experiences and other mental states, and believes that it is itself such a continuing entity' (3). In brief, self-consciousness and what goes with it is what constitutes us as persons. Within this perspective what is valued in human beings, ie that which leads us to believe that they have moral claims upon us, is the actual exercise of capacities associated with self-consciousness. It should be noted that the moral claims upon us even of fullfledged persons are from this point of view not held to be absolute; for specific claims upon us (ie rights which imply correlative obligations) are not based on the simple fact of 'personhood'; rather they are based on the express desires of persons, which may change. So the right a person may have not to be killed is waivable 
if he desires to be killed. Personhood is itself not valuable; what is ultimately valuable about being a person is that you have reached that stage of development at which, having the required conceptual equipment, you are in a position to express that range of desires, satisfaction of which is alone morally significant. (Animals are capable of expressing their desires, such as the desire not to suffer pain, as much as humans are; hence, in this view, they also have rights based on those desires; they have moral claims upon us).

(ii) Those adhering to these views maintain that the particular moment at which a human being becomes a person, i e turns into a person by acquiring a concept of self and a range of other concepts necessary to having and expressing desires, is a matter of empirical determination. This determination can be left to the psychologists and is relatively unproblematic.

\section{(b) Development of a person.}

In this approach, in contrast with the previous one, to be a human being is to be a person. There are no stages in our existence at which this identity does not hold. If this is so the concept of a person cannot be determined by, or restricted to, a stage - or state - of selfconsciousness. Also, and as a consequence, rights are not to be founded on self-conscious desires, and so they are not necessarily connected with states of consciousness. Thus, within this outlook two questions must be answered as well: (i) if what makes someone a person is not self-consciousness, and the belief that one is that continuing self, what is it and (ii) if fundamental rights (and obligations) are not based on conscious desires, on what are they based, and how are they related to personhood?

(i) What makes us persons is the kind of beings we are, the kind of nature we possess, and not a passing state or stage of that kind of being. I will undertake to make good these claims in the light of two principles which for convenience may be called: the principle of unity and the principle of potentiality. By the principle of unity is meant that human beings - like any other creatures - are just one entity, one being, and not a composite of two things. They are not first physical organic bodies with (at a later stage) personhood added to them by self-consciousness, making them human beings and persons. They are not human organisms first and persons only subsequently, in virtue of the advent of a 'soul' or consciousness. Human beings are what they are on the basis of their specific organic make-up, with its proper structure, dynamism, capacities and activities. Both our organism and capacities are inseparably one and of a specific kind, of a 'human' kind we say, that is why we call ourselves 'human' beings. Our organic make-up, in its molecular structure (the human genes) as well as in its bodily form (the human face and hands, the human brain and feet, the human eyes) are not something separable from, or something capable of being abstracted from, the capacities they express and realise, capacities the exercise of which is living for us: eating, drinking, sleeping, movement from place to place, smiling, laughing, speaking a language, hoping, being open or narrow minded, pursuing ends, choosing means,? adopting attitudes, determining the course of one's life. It has been rightly noted that when the idea of consciousness is completely separated from, abstractede from, humanity and human life, philosophers develop two typical syndromes, of which one is 'a dire suspicion that anything at all may be a subject of consciousness 0 (4), eg animals or a brain in vitro might be suches subjects. We appropriately consider ourselves to be part of the animal kingdom because of our bodilycondition. Yet our bodily condition is not somethingw apart from what we distinctively are, with all ous capacities and activities, including self-consciousness $\underset{x}{\overrightarrow{0}}$ self-determination, responsibility, love and creativity $\vec{\circ}$ Because of all these, we see ourselves as different from other creatures and regard ourselves as persons. We्w acknowledge that we are the only beings that because of our human body and capacities live and respond to reality and to others in a personal way. It is also in virtue $\vec{z}$ of what we are as a unity of body and capacities ando activities, that we regard ourselves as belonging to one $f$ and the same family, one and the same species, long described as homo sapiens. Members of this specieso manifest their personal form of life not only individually but socially. We are the only creatures thato live culturally, that manifest their higher form of life in the so called universals of culture, namely, linguistico activity, conscience, art and aesthetic appreciation religion, political life and technology. Indeed bodily form (or organic form) and capacities are the tw $\overrightarrow{0}$ inseparable dimensions and determinants of any $\bar{B}$ species, of any members of the animal kingdom making them what they are in their specific nature? What things can do and how they appear is manifestation of what they are. It is what they are that determines what they can do, not the other way? around. So if we can attain self-consciousness at some stage, we must already be the kind of beings that can attain it. The inseparability of what a thing is and its capacities is particularly manifested in its organic continuity, in its being always the same organism. This question of continuity leads us to the principle of potentiality. The bodily person I am now certainly began as a tiny organism of one cell, a human zygote. If this original cell was capable of developing into me N what capacities and potential did it have then? This is the crucial question that must be answered. The development of personal abilities (self-awareness choice, creativity) does not come about independently of our organic development. There are no bases in reality to affirm that those capacities are 'something added' (by miracle?) at any particular stage. Thus if wफ्ठ are to make sense of our existence now as humar? personal beings, we must admit that whatevep capacities we have now have developed from what we were from the beginning. Our present abilities are onlyo explicable if there was always a presence of the inheren capacity for those abilities in the human organism froms. 
the beginning. To say that only at some later stage of development do we have the exercisable abilities of selfconsciousness and self-determination, while true, leaves unexplained the origin and development of these abilities; and failure to recognise the need for explanation at this point results in failure to acknowledge the nature of the subject to which the abilities belong. The value of a being is indeed related to the things into which it can develop, but not independently of, but precisely because of what the being is. For the actual capacity to achieve a particular type of development must always have been present prior to development, and is therefore significant in determining what kind of being we are dealing with, even in the earliest stages of its existence.

We know that a new human individual organism with the internal potential to develop into an adult, given nurture, comes into existence as a result of the process of fertilisation at conception. We must reckon then that such a potential is an actually present capacity which in the normal course of development will come to be more or less fully manifested in the personal life of an adult. Hence, the kind of life that the zygote has, because of the capacity it presently possesses, is personal life, i e the life of a personal being or a personal subject. It is this presence of personal capacities which must be attributable to a personal subject - that makes a difference between one kind of life (that of human persons) and another (that of say, dogs). It must also be noted that living entities are not machines built up out of blocks. The development of a living entity, becoming what it is capable of being, is indeed a process, but the entity itself and its coming to be, is not. At any particular time, the entity is in toto or it is not at all (this is an important consideration for the debate about brain death as well). For living human beings are not like, for example, clocks, that progressively come to be and can be assembled and dismantled. Whereas you can reasonably speak of having half a clock, you cannot reasonably speak of having half a person.

(ii) Let us now turn to the question of basic rights. It is in virtue of what things are that we treat them one way or another; it is in virtue of what human beings are, right from the beginning of their existence, that they must be accorded absolute respect and their lives treated as inviolable. Rights are based on values, and values on the recognition of what things are. The ultimate ground of value is being, not passing states of beings, like activities and desires; for these are the manifestations of what the being is. What one can become is a possibility based on what one is. Becoming has its only basis in being. Every potentiality must be based on something actual, on a real actuality. Basic rights (and obligations), like the right not to be killed and the obligation not to kill an innocent human being, are based on what human beings are, not on particular states of conscious desires. Thus from this perspective what is valued in human beings is themselves, what they are, and not just what they achieve.

\section{What is morally desirable}

In the strict sense IVF is not a medical problem, ie a problem arising from concern for health and the development of means to restore or improve health. Rather it is one of an increasing number of biotechnical problems ie problems arising from the development of techniques designed to circumvent or modify existing (usually defective) modes of bodily function. These biotechnical developments along with other scientific developments 'threaten to turn homo sapiens into homo mechanicus' as has recently been noted in this journal (5). Although this is a general point, it is one of great significance in relation to the direction medicine is now taking. It cannot be ignored in our evaluations of medical progress and development.

Having said that, let me turn to our main question. What kind of respect is due to the human embryo? Is the human embryo to be protected as a human being or as property? The only possible answer, in the light of the considerations advanced in the previous section, is that respect due to the human embryo must not differ in kind from the respect due to any other human being; the human embryo must be protected as a human being, not as a property or an object of use. This means that the human embryo has the right not to be killed and not to be used or exploited for any purpose whatsoever.

This makes clear that a form of study which risks harm to human embryos and experimentation on human embryos for scientific purposes is immoral. Such experiments are never in the interest of the subject experimented upon, who is harmed, used up and destroyed, always being treated radically as a means, as an object of use, as a 'product', as 'material' - to use favourite dehumanising terms in vogue in the literature.

In the context of alleviating infertility, a number of spare embryos are generated as the most economic procedure for attaining the general aim in view - the greater chances of pregnancy with the minimum of effort, expense and trauma. Yet the well-being and existence of each individual life thus generated is made secondary and as such instrumental to the general aim. Those lives, if not required for the desired pregnancy, will be disposed of, used for experiments, or frozen until a time comes when they will be in demand for implantation, experimentation or disposal. The common practice of superovulation clearly involves an immoral instrumentalisation of the embryo.

Nature 'prodigally' disposes of large numbers of embryos, even without being noticed by the women who carry them, we are told. Hence, some ask, if nature is so prodigal with so many embryos, why are we not entitled to generate some that can be used for the benefit of others or of science and when required destroyed, or disposed of? First, it should be remarked that even if it were true that many embryos die naturally that would not be a fact which told us what kind of being the embryo is, and so what kind of 
respect is owed to it. Second, natural processes such as floods, droughts, volcanic eruptions and other kinds of natural disasters are natural processes as much as the processes whereby the loss of fertilised ova naturally occur. These processes cannot be taken as indicative of what we are to do, of the actions we are to choose. To think otherwise is to ignore the fact that what we intend, decide and deliberately bring about are not (in this sense) natural processes (and just because they are not, we are answerable for them). Hence they cannot be measured against the results that nature brings about. We are moral beings. Physical nature is not.

Irreparable damage to the embryo or the child-to-be is a feature of IVF procedures which cannot be excluded. This is clearly acknowledged by, for example, Dr Edwards, when he mentions the back-up methods of monitoring abnormalities after IVF and implantation, and suggests in vitro abortion (6). This risk is implicitly recognised by the recent Royal College of Obstetricians and Gynaecologists' (RCOG) report on IVF when it claims 'the possibility that a child born with an abnormality might in due course be able to sue its parents and the doctors cannot be ruled out' (7). We are not morally justified in directly engaging in bringing about such risk of harm. In natural procreation an abnormal embryo might or might not abort. In the IVF process it must be destroyed. In natural procreation the child is conceived and received unconditionally 'for better or for worse'; in the IVF programme only conditionally 'for better', so primarily not for his or her own sake, but for the satisfaction of a desire. It needs to be recognised that the well-being of the child should be of paramount importance - as that of any other human being; recognition should be embodied in attitudes and practices which exclude treating the child as a commodity, a property or mere object of satisfaction at any stage of his or her existence.

One should welcome the fact that Singer and Wells recognise that secrecy over gamete donation (as may occur in artificial insemination by donor (AID) or in $\underset{+}{ }$ surrogate motherhood) need not be maintained. Openness will indeed encourage greater responsibility and attitudes of trust and truth in all those involved. $\overrightarrow{\overrightarrow{\mathrm{F}}}$ Yet meeting the requirements of openness hardly meets all the objections to these practices. The practices not only put the well-being of the child at risk $\overline{\bar{\omega}}$ but surrogate motherhood in particular involves a $\vec{\Phi}$ direct instrumentalisation of the feminine power of $\propto$ gestation. The phrase 'rent-a-womb' fairly aptly œै characterises the instrumentalisation in question; for $\vec{\circ}$ whether one pays or not, the woman's body becomes usable accommodation. Neither children born or $\vec{\omega}$ unborn, nor women, nor the rest of mankind are ever to be property, but beings to be respected, cared for $\overparen{\mathrm{D}}$ and loved for their own sake, and not with a view to $\vec{\circ}$ achieving other purposes. We all have to grow in that rare virtue that men of great stature have shown: to $\omega_{N}$ love human beings just because they are human beings.

\section{References}

(1) Singer P, Wells D. In vitro fertilisation: the major issues $\frac{\widehat{\partial}}{\supset}$ (with comment by Mitchell G D and a response by Singer $\vec{\bullet}$ and Wells). Fournal of medical ethics 1983; 9: 192-199.

(2) Walters W, Singer P, eds. Test-tube babies. Oxford $\$$ University Press, 1982; 60.

(3) Tooley M. Abortion and infanticide. In: Cohen M, Nagel $\mathrm{T}$, Scanlon $\mathrm{T}$. eds. The rights and wrongs of abortion. Princeton; A Philosophy and Public Affairs Reader, 1974: 59.

(4) Teichman J. Wittgenstein on persons and human beings. Royal Institute of Philosophy lectures. London: Volume 7; 1972/1973: 135-136.

(5) Jakobovits Sir I. Jewish medical ethics - a brief overview. Fournal of medical ethics 1983; 9: 112.

(6) Edwards R G, Purdy J M, eds. Human conception in vitro. London: Academic Press, 1982: 372-373.

(7) Report of: the Royal College of Obstetricians and $\stackrel{(1)}{\sigma}$ Gynaecologists Ethics Committee on in vitro fertilisation and 3 embryo replacement or transfer. London: March, 1983: Sec $10,7$. 